\title{
Influence of physicochemical parameters of water on the amino acid composition of bread kvass
}

\author{
Olha Dulka1, Vitalii Prybylskyi ${ }^{1}$, Svitlana Oliinyk ${ }^{1}$, \\ Anatolii Kuts ${ }^{1}$, Oksana Vitriak ${ }^{2}$ \\ 1 - National University of Food Technologies, Kyiv, Ukraine \\ 2 - Kyiv National University of Trade and Economics, Kyiv, Ukraine
}

\section{Keywords: \\ Kvass \\ Amino acids \\ Water \\ Clinoptilolite \\ Activated carbon \\ Rock crystal}

\section{Article history:}

\section{Received}

30.01 .2020

Received in revised

form 24.07.2020

Accepted

30.09.2020

\section{Corresponding \\ author:}

Olha Dulka

E-mail:

olga.ds210791@

gmail.com

DOI:

$10.24263 / 2304-$

974X-2020-9-3-10

\section{Abstract}

Introduction. The influence of drinking water, which was prepared with the help of clinoptilolite, rock crystal and activated carbon, on the amino acid composition of wort and kvass was determined.

Materials and methods. Water was prepared by treating it with clinoptilolite, activated carbon and rock crystal. The fermented wort was obtained by fermentation of rye-based wort with yeast Saccharomyces cerevisiae MP-10. The amino acid composition of wort and kvass was determined by ion exchange chromatography, the dynamics of kvass wort fermentation was determined by fermentation test.

Results and discussion. As a result of water treatment with clinoptilolite, activated carbon and rock crystal, the total hardness was reduced from 4.5 to $1.1 \mathrm{mmol} / \mathrm{dm}^{3}$, the permanganate oxidationwas reduced from 4.0 to $0.5 \mathrm{mg} \mathrm{O} / \mathrm{dm}^{3}$, iron and residual chlorine were removed completely.

The change in the mineral composition of water significantly affected the course of the technological process, quantitative and qualitative amino acid composition of wort and kvass. The use of prepared water improved the qualitative amino acid composition, increased their total content in the initial wort from 3.3 to 8.87 $\mathrm{mg} / 100 \mathrm{~g}$, in particular amountof essential amino acids improved from 0.44 to $3.31 \mathrm{mg} / 100 \mathrm{~g}$, which reduced their resynthesis, reand deaminationby yeast cells. The total amount of amino acids in the fermented wort with using prepared water was $9.88 \mathrm{mg} / 100 \mathrm{~g}$, in the control it was $5.57 \mathrm{mg} / 100 \mathrm{~g}$.

The ratio of amino acids in the wort had significant differences, in particular the content of proline, which is difficult to digest by the yeast cell when using prepared water, was $14 \%$, and for the control sample it was $30 \%$.

Intensification of the process of yeast cells culturing increased their concentration in the culture fluid for 24 hours from 96.8 to $85.1 \mathrm{million} / \mathrm{cm}^{3}$, as well as reduced the duration of fermentation of kvass wort from 15 to 13 hours.

The amino acid score of kvass, which was made withusing prepared water in the stages of yeast cultivation and fermentation of yeast wort, was more acceptable compared to the method with untreated water.

Conclusions. The use of prepared water with clinoptilolite, rock crystal and activated carbon in kvass technology improves the qualitative amino acid composition and increases their total content in the initial and fermented wort. 


\section{- Food Technology -}

\section{Introduction}

The chemical composition of most soft drinks is unbalanced, which is due to the use of mainly sucrose and dietary supplements with low or no protein, dietary fiber, vitamins, minerals and other biologically active substances $[1,2]$.

Bread kvass, which is prepared on the basis of rye raw materials, is a traditional Slavic drink and contains a wide range of biologically active substances [3, 4].

The drink is obtained by incomplete combined alcohol and lactic acid fermentation [4, 5]. In this case, due to the activity of yeast and lactic acid bacteria, a complex of biologically active substances is formed. However, to simplify the technology, often only yeast is used, and the required acidity is achieved by adding lactic acid $[3,6,7]$.

In the process of fermentation, the caloric content of the beverage decreases, the amount of digestible nutrients increases, and the biological value increases $[3,8]$. However, the search for ways to increase the biological value of kvass remains relevant.

Quantitative and qualitative amino acid composition of most soft drinks is very limited [9]. Therefore, in the production of kvass it is important to preserve and accumulate in the fermentation process the maximum possible and balanced amount of amino acids, mainly essential, which determines the usefulness of the drink, affects the process and indicators of the finished product $[1,10]$.

It is known that the yeast Saccharomyces cerevisiae absorbs inorganic nitrogen, in particular ammonium sulfate, urea, ammonia salts of acetic, lactic, malic and succinic acids, as well as most amino acids [11]. However, some of the amino acids (proline, histidine, glycine, cystine) are difficult for cells to digest [12]. Therefore, it was important to conduct research to determine the effect of the amino acid composition of kvass wort on the physiological activity of yeast.

For the production of fermented beverages water from centralized water supply networks or from artesian wellsis used [13]. In the first case, the water is already reduced to drinking condition, and in the second, which is more common [3], may not meet such requirements. There are additional requirements for process water in non-alcoholic production [14], but they are absent for kvass production. In many cases, water-softened Nacationite filters are used, but such treatment only replaces calcium and magnesium ions with sodium ions [15]. Therefore, it is important to improve the technology of water treatment with the use of effective and practically convenient natural minerals of various types during mechanical filtration.

Water treatment using mechanical filters with natural mineral backfill (quartz sand, gravel) does not fully ensure the quality of prepared water by organoleptic, physicochemical and microbiological parameters [5]. Therefore, it is important to improve the mechanical filtration of water with the use of new effective natural materials, including minerals. Due to strictly defined pore sizes and internal cavities, they are effective sorbents of organic and inorganic substances [16]. Such materials have the ability to improve the organoleptic and physicochemical parameters of water, to ensure its structuring, which increases the health effects of the finished drink $[3,13]$.

The use of minerals can solve various problems [4]. Sorption processes can be provided not only by the use of activated carbon and its analogues (graphite-mineral sorbents) [15]. For these purposes, as well as a filter material, it is advisable to use zeolites, in particular clinoptilolite [17].

Due to the specific structure of clinoptilolite, which is a tetrahedron with octagonal rings on the tops containing alkaline and alkaline earth metals inside the cations and a significant 
number of entrance windows $\left(3.5-4.8 \mathrm{~A}^{0}\right)$ and channels, its use as a molecular sieve with ion exchange properties is ensured [15].

The aim of the work is to study the effect of clinoptilolite, rock crystal and activated carbon in the preparation of water on the amino acid content in the original and fermented wort to improve the viability of yeast and obtain the finished drink with balanced amino acid composition.

\section{Materials and methods}

\section{Water treatment using clinoptilolite, activated carbon and rock crystal}

Tap water treatment was performed with clinoptilolite of Sokyrnytsia deposit (Ukraine), activated carbon and rock crystal at a speed of $8-15 \mathrm{~m} / \mathrm{h}$. Water was prepared in a cyclic mode with the following sequential operations:

- Preparation of materials;

- Water filtration to reach the limit values: clinoptilolite for hardness; rock crystal for transparency; activated carbon for transparency, color and permanganate oxidation;

- Padding of a layer of materials with a stream of untreated water for prevention of caking and removal of dirt from their surface;

- Regeneration of clinoptilolite.

The use of clinopylolite is due to the fact that it reduces the hardness of water and removes heavy metals [17].

Activated carbon was used to reduce the content of organic impurities and improve the organoleptic characteristics of water [3].

Rock crystal was used to structure the water, adjust the redox potential and remove foreign microflora [15].

In the prepared water the content of total iron was $0.01 \mathrm{mg} / \mathrm{dm}^{3}$, total hardness 1.1 $\mathrm{mmol} / \mathrm{dm}^{3}$, permanganate oxidation $0,5 \mathrm{mg} \mathrm{O} \mathrm{O}_{2} / \mathrm{dm}^{3}$. Untreated water with a total iron content of $0.05 \mathrm{mg} / \mathrm{dm}^{3}$, a total hardness of $4.5 \mathrm{mmol} / \mathrm{dm}^{3}$, and a permanganate oxidation of 4.0 $\mathrm{mg} \mathrm{O} / \mathrm{dm}^{3}$ was used as a control.

\section{Preparation of kvass wort and kvass}

For the cultivation of yeast, wort was prepared from a concentrate of kvass wort, sugar syrup and water with concentration of $7.0-8.0 \%$ of dry matter [13]. The wort for kvass preparation was prepared to a dry matter concentration of 3.4-3.6\%, it was fermented with a pure culture of yeast Saccharomyces cerevisiae MP-10, which was selected from acidic concentrate of kvass wort (patent № 134310 Yeast strain Saccharomyces cerevisiae MP-10 using for fermentation in the production of fermented beverages) with the initial yeast cells concentration of 0,6 million $/ \mathrm{cm}^{3}$ at a temperature of $34{ }^{\circ} \mathrm{C}$ to reduce the dry matter content by $0.8-1.0 \%$. The fermented wort released from the yeast sludge was blended to a dry matter content of $5.4-5.6 \%$ [4].

Two samples of kvass wort were prepared:

- Control - wort with untreated water;

- Experiment - wort with prepared water. 


\section{Determination of yeast fermentation activity}

The concentration of yeast cells in the culture fluid was determined using the Goryaev chamber [18], the dynamics of fermentation of yeast wort was determined by biological method.

\section{Determination of amino acid content}

The amino acid composition of wort and kvass was determined by ion exchange chromatography on Biotronik Amino Acid Analyzer LC2000 equipment with amino acid distribution using ion exchange resin and tribuffer system. Identification was performed by reaction with ninhydrin and detection with photocolorimetery and electrophoresis methods using the system «Drops-105/105M», which involves acid hydrolysis with the transition of amino acids into free forms with their subsequent separation and quantification by capillary electrophoresis. Detection was performed in the UV region of the spectrum at a wavelength of $254 \mathrm{~nm}$ [4].

\section{Determination of amino acid score}

To characterize the biological value of kvass, we compared their amino acid composition with the ideal scale of amino acids $[19,20]$. Amino acid score was calculated by the formula:

where:

$$
\mathrm{C}=(\mathrm{A} / \mathrm{H}) \cdot 100 \text {, }
$$

$\mathrm{C}$ is score, \%;

A is amino acid content in kvass, $\mathrm{mg} / \mathrm{g}$ protein;

$\mathrm{H}$ is the amino acid content in an ideal protein, $\mathrm{mg} / \mathrm{g}$ protein.

\section{Results and discussion}

\section{Influence of filter materials on physicochemical parameters of water}

Water used for the production of fermented beverages must be epidemiologically safe, harmless in chemical composition and have acceptable organoleptic properties [13, 21]. Table 1.

Physicochemical parameters of control and experimental water samples are given in

It is established that the joint use of the studied rawmaterials provided the necessary physicochemical parameters of process water. The total hardness was reduced by $82 \%$, the permanganate oxidation was reduced by 3.6 times, iron and residual chlorine were removed completely.

In the first stage, the water was treated with clinoptilolite to reduce stiffness and remove mechanical impurities [15]. This reduces the load on the carbon filter, which increases its service life [4]. Treatment of water with activated carbon in the second stage provided sorption of impurities, stabilization of the redox potential and improvement of organoleptic characteristics [3]. The third stage involves the treatment of water with rock crystal for its structuring and design of organoleptic characteristics [13]. 
Influence of filter materials on physicochemical parameters of water

Table 1

\begin{tabular}{|c|c|c|c|}
\hline le name & $\begin{array}{c}\text { Dry residue, } \\
\mathbf{m g} / \mathbf{d m}^{3}\end{array}$ & $\begin{array}{c}\text { Total } \\
\text { stiffness, } \mathbf{m m o l} / \mathbf{d m}^{3}\end{array}$ & $\begin{array}{l}\text { Total iron, } \\
\mathbf{m g} / \mathbf{d m}^{3}\end{array}$ \\
\hline & 251.0 & 4.5 & 0.05 \\
\hline Experiment & 205 & 1.1 & less than 0.01 \\
\hline
\end{tabular}

\begin{tabular}{|c|c|c|c|c|c|}
\hline Sample name & $\begin{array}{c}\mathrm{Cl}^{-}, \\
\mathrm{mg}^{2} \mathrm{dm}^{3}\end{array}$ & $\begin{array}{c}\mathrm{NO}_{3}^{-}, \\
\mathrm{mg}^{-} \mathbf{d m}^{3}\end{array}$ & $\begin{array}{c}\mathrm{SO}_{4}^{2-} \\
\mathrm{mg}^{2-} \mathrm{dm}^{3}\end{array}$ & $\mathbf{p H}$ & $\begin{array}{c}\text { Permanganate } \\
\text { oxidation, } \\
\mathrm{mg} \mathrm{O}_{2} / \mathbf{d m}^{3} \\
\end{array}$ \\
\hline Control & 34 & 4.6 & 37 & 7.39 & 4.0 \\
\hline Experiment & 15 & less than 0.05 & 15 & 8.10 & 0.5 \\
\hline
\end{tabular}

\section{Effect of water on the amino acid composition of the original kwass wort}

The main amine nutrition for yeast in kvass wort is free amino acids [22], which directly affect their physiological activity [23, 24]. Table 2 shows the amino acid content in the studied samples of kvass wort.

Amino acid composition of kvass wort

Table 2

\begin{tabular}{|l|c|c|}
\hline \multirow{2}{*}{ Amino acids } & \multicolumn{2}{c|}{ The content of amino acids in the wort, mg / 100 g } \\
\cline { 2 - 3 } & Control & Experiment \\
\hline Aspartic acid & 1.65 & 2.85 \\
\hline Threonine & 0 & 0.42 \\
\hline Serine & 0.16 & 0.39 \\
\hline Glutamic acid & 0 & 0.05 \\
\hline Proline & 0.97 & 1.25 \\
\hline Glycine & 0 & 0.05 \\
\hline Alanine & 0 & 0.74 \\
\hline Valine & 0.05 & 0.34 \\
\hline Methionine & 0 & 0.06 \\
\hline Isoleucine & 0.02 & 0.33 \\
\hline Leucine & 0.04 & 0.45 \\
\hline Tyrosine & 0 & 0.29 \\
\hline Phenylalanine & 0 & 0.94 \\
\hline Histidine & 0.33 & 0.45 \\
\hline Arginine & 0 & 0 \\
\hline Lysine & 0 & 0.03 \\
\hline Essential & 0.44 & 3.31 \\
\hline Non-essential & 2.86 & 5.56 \\
\hline Total & 3.30 & 8.87 \\
\hline
\end{tabular}


The obtained data indicate the presence of seventeen amino acids in the kvass wort, in particular 9 essential ones. When using the prepared water, the total amino acid content in the kvass wort was higher by $63 \%$, in particular essential ones by $87 \%$. The content of inorganic nitrogen (ammonium salt) in the test sample increased almost threefold (from 0,08 to $0,23 \mathrm{mg} / 100 \mathrm{~g}$ ). The significant difference in the content of amino acids in the studied samples can be explained by the mineral composition of the untreated water, in particular the increased amount of hardness salts, which while interacting with organic acids change the acidity of the wort.

Amino acids in solutions exhibit the properties of amphoteric electrolytes. Depending on the $\mathrm{pH}$ of the medium, they can have acidic or alkaline properties. In an acidic environment, the dissociation of the carboxyl group is inhibited, the amino acid molecule thus acquires a positive charge and reacts as a cation:

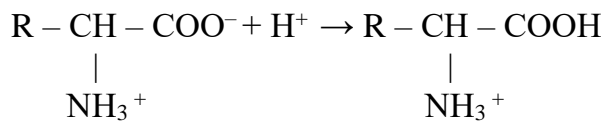

In an alkaline environment, under the action of $\mathrm{OH}$ - ions, the ionization of amino groups is inhibited, the amino acid molecule acquires a negative charge and reacts as an anion:<smiles></smiles>

The $\mathrm{pH}$ value of the medium at which the total charge of the amino acid is zero is called the isoelectric point [25-27]. Therefore, the $\mathrm{pH}$ of the wort has a significant effect on the process. Table 3 shows the acidity of the kvass wort of the test samples.

Acidity of kwass wort

Table 3

\begin{tabular}{|l|c|c|}
\hline \multicolumn{1}{|c|}{ Sample name } & $\begin{array}{c}\text { Titrated acidity, } \mathbf{~ c m}^{\mathbf{3}} \text { of } \mathbf{~ N a O H} \text { solution conc. } \\
\mathbf{1 ~} \mathbf{~ m m o l} / \mathbf{d m}^{\mathbf{3}} \text { per } \mathbf{1 0 0} \mathbf{~ c m}^{\mathbf{3}} \text { of wort }\end{array}$ & pH \\
\hline Control & 0.9 & 5.94 \\
\hline Experiment & 1.2 & 5,45 \\
\hline
\end{tabular}

It is known that the isoelectric point for monoaminomonocarboxylic acids corresponds to $\mathrm{pH}$ 6. In isoelectric points of amino acids are the least stable and precipitate directly and in the form of salts. According to the data, the active acidity of the wort of the control sample in contrast to the experimental was close to this value.Therefore, the content of monoaminomonocarboxylic acids in the test sample was $2.78 \mathrm{mg} / 100 \mathrm{~g}$, which is 10 times higher than in the control (see Table 2).

Yeast assimilates amino acids in different sequences [26]. Table 4 shows the distribution of amino acids by their digestibility. 
Distribution of amino acids by digestibility by yeast species Saccharomices cerevisiae

\begin{tabular}{|c|c|c|c|}
\hline Class 1 & Class 2 & Class 3 & Class 4 \\
\hline Arginine & Histidine & Alanine & Proline \\
\hline Aspartic acid & Isoleucine & Glycine & - \\
\hline Glutamic acid & Leucine & Phenylalanine & - \\
\hline Lysine & Methionine & Tryptophan & - \\
\hline Serine & Valine & Tyrosine & - \\
\hline Threonine & - & - & - \\
\hline
\end{tabular}

Figures 1 and 2 show the ratio of the above classes of amino acids in the studied samples of wort.

These data indicate that the test sample contained a larger range of amino acids compared to the control, which promotes their assimilation by yeast in the first stage of reproduction with little resynthesis, re- and deamination [26]. In this case, amino acids are used by cells for protein synthesis directly, and therefore their assimilation is more efficient [4]. The content of proline, which is difficult to digest by the yeast cell was 2 times less than in the control. It should also be noted that the test sample, in contrast to the control, contained methionine, which is a partial source of phosphorus nutrition for yeast [19].

The assimilation of amino acids by yeast occurs in two ways, one of which is associated with deamination and the other with decarboxylation [27, 28]. Decarboxylation occurs according to the equation:

$$
\mathrm{RCHNH}_{2} \mathrm{COOH} \frac{\text { pyrodoxal }}{\text { proteid }} \rightarrow \mathrm{RCH}_{2} \mathrm{NH}_{2}+\mathrm{CO}_{2}
$$

The deamination reaction is associated with the release of ammonia from the amino acid by the equation:

$$
\mathrm{RCHNH}_{2} \mathrm{COOH}+\frac{1}{2} \mathrm{O}_{2} \rightarrow \mathrm{RCOCOOH}+\mathrm{NH}_{3}
$$

The deamination process is associated with reamination reactions. These two processes allow cells to synthesize amino acids most intensively [29].

\section{Influence of water treatment on the process of yeast cultivation and kvass wort fermentation}

Qualitative and quantitative composition of amino acids of wort determines the biosynthetic processes of yeast cells and directly affects the rate of their growth [3, 13]. Tables 5, 6 show a comparative characteristic of the concentration of yeast cells and their specific growth rate during cultivation. 


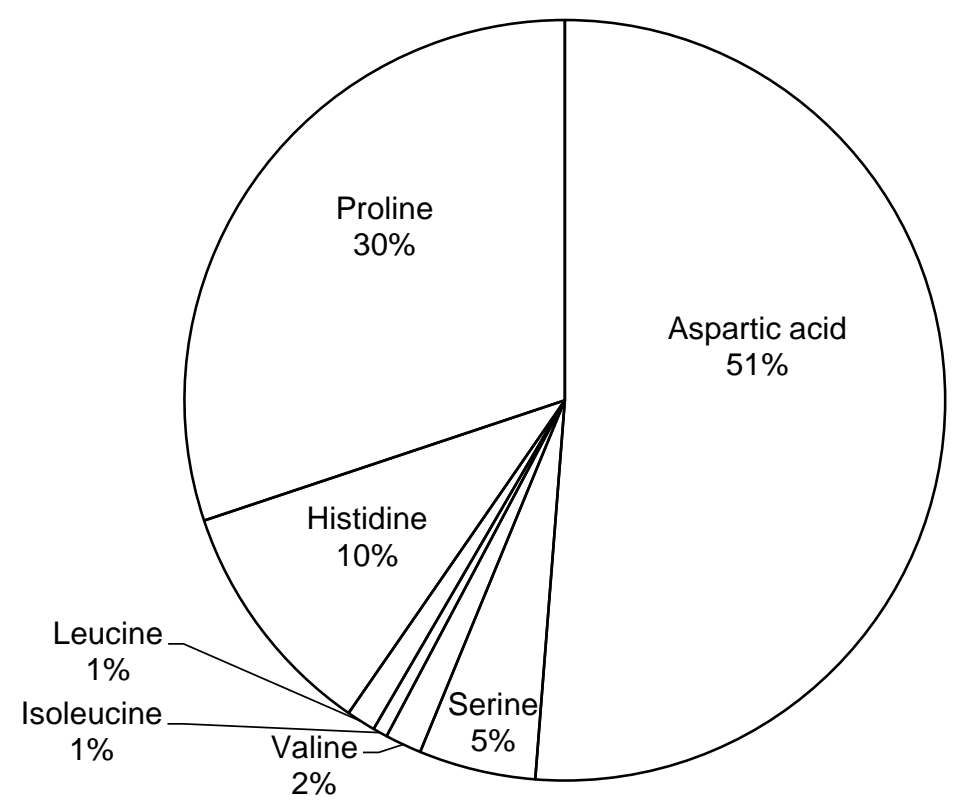

Figure 1. The ratio of amino acids in the wort when using untreated water (control)

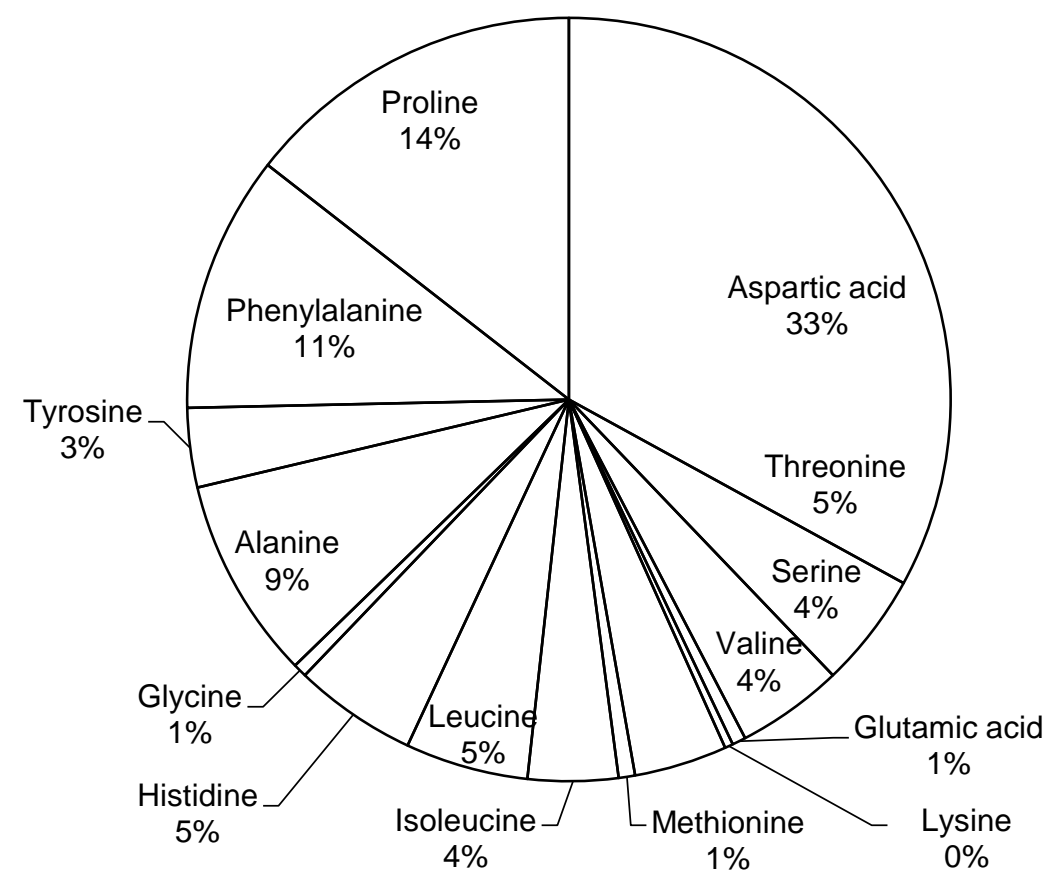

Figure 2. The ratio of amino acids in the wort when using prepared water (experiment) 
Influence of cultivation duration on yeast cell accumulation

\begin{tabular}{|c|c|c|}
\hline \multirow{2}{*}{ Duration, hours } & \multicolumn{2}{|c|}{ Yeast cell concentration, $\mathbf{m} / \mathbf{m} \mathbf{c m}^{\mathbf{3}}$} \\
\cline { 2 - 3 } & Control & Experiment \\
\hline 0 & 0.5 & 0.5 \\
\hline 6 & 3.7 & 8.1 \\
\hline 12 & 54.1 & 61.5 \\
\hline 18 & 78.2 & 89.0 \\
\hline 24 & 85.1 & 96.8 \\
\hline
\end{tabular}

Throughout the cultivation process, the content of yeast cells in the test sample was higher than in the control: after 6 hours $-54 \%$, the next - an average of $12 \%$, which can be explained by the increased content of amino acids in the wort used as a source of amine nutrition for yeast. These data indicate a positive effect of a more balanced nitrogen nutrition of the experimental sample of yeast wort on the accumulation of yeast cells.

Effect of cultivation duration on the specific growth rate of yeast

Table 6

\begin{tabular}{|c|c|c|}
\hline \multirow{2}{*}{ Duration, hours } & \multicolumn{2}{|c|}{ Specific growth rate $(\boldsymbol{\mu}), \mathbf{h}^{-\mathbf{1}}$} \\
\cline { 2 - 3 } & Control & Control \\
\hline 6 & 0.333 & 0.464 \\
\hline 12 & 0.447 & 0.337 \\
\hline 18 & 0.061 & 0.062 \\
\hline 24 & 0.014 & 0.014 \\
\hline
\end{tabular}

When comparing the studied samples, it was found that the maximum specific growth rate of the experimental sample was 3,6\% higher for the experimental sample compared to the control. Achieving high growth rate by the sixth hour of growth for this sample $(28 \%$ more than in the control) indicates a reduction in the lag phase and accelerating the beginning of the phase of exponential development of yeast [9]. Subsequently, the specific growth rate of yeast in the experimental and control samples did not differ. The obtained results can be explained by the expanded qualitative composition of amino acids in the experimental sample, which are not close to the isoelectric point and do not precipitate. After 18 hours in the culture medium there was a phase of cell death, which was accompanied by a decrease in the specific growth rate.

Figure 3 shows the dynamics of the decrease in dry matter content during the fermentation of wort by yeast at the initial cells content in the inoculumof 61 million $/ \mathrm{cm}^{3}$ in the phase of their exponential growth. 


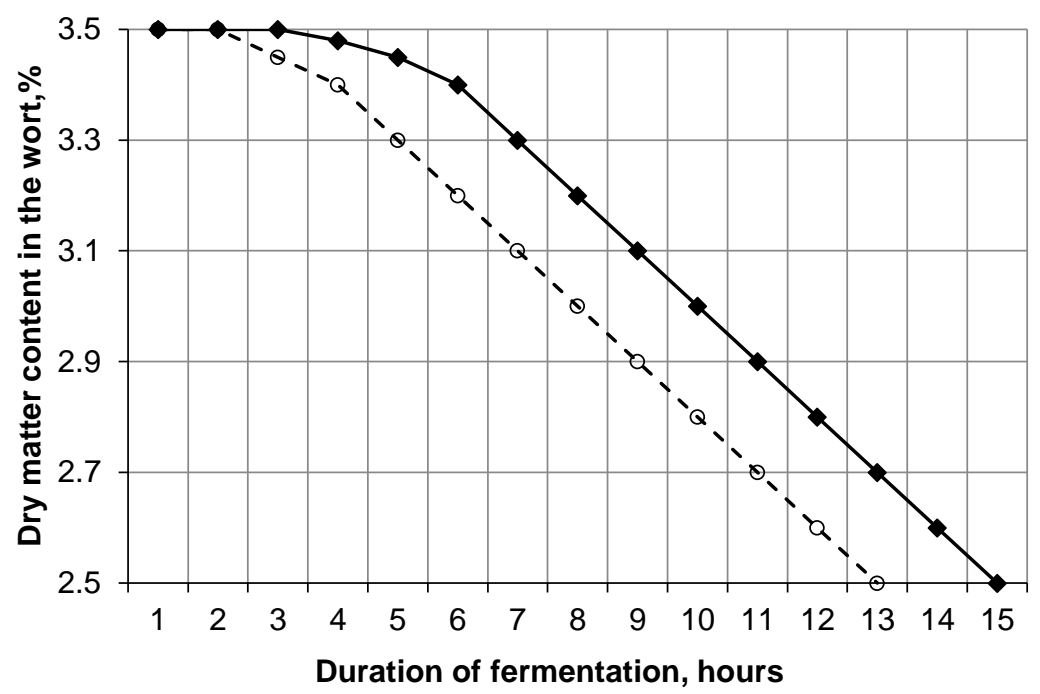

$\longrightarrow$ Control - - - - Experiment

Figure 3. Dynamics of dry matter content during fermentation of kvass wort

The general nature of the fermentation process in the studied samples was similar. However, in the experimental sample the beginning of intensive fermentation was observed from the second hour, and in the control - from the third, which can be explained by more active physiological state of yeast, reducing the duration of their adaptation to environmental conditions [26], increased initial amine nitrogen content. In addition, calcium, magnesium, and sodium ions, which reduce the permeability of the yeast membrane, had a negative effect on the control sample [29]. The required decrease in dry matter content (by $0.8-1.0 \%$ ) for the test sample occurred on average by 2 hours faster than control.

\section{Effect of water on the amino acid composition of fermented kvass wort}

It was found that the treated water allowed not only to preserve most of the amino acids of the kvass wort concentrate, but also to optimize their quality ratio (see Table 2). At the same time, full nutrition of yeast was provided and fermentation was accelerated, the influence of resynthesis, re- and deamination processes was significantly reduced (Figures 1, 2). It should be kept in mind that amino acids are the component not only of cell organelles, but also of enzymes and vitamins [26]. Alanine is part of pantothenic acid, which plays an important role in the life of yeast [9]. Glutamic acid is involved in the construction of enzymes that catalyze the synthesis of purine bases and peptides [19]. In addition, the qualitative composition of amino acids used for protein synthesis directly affects the stability of RNA [28, 29].

Figures 4 and 5 show the comparative characteristics of the amino acid composition of the original and fermented wort using the yeast Saccharomyces cerevisiae MP-10. 


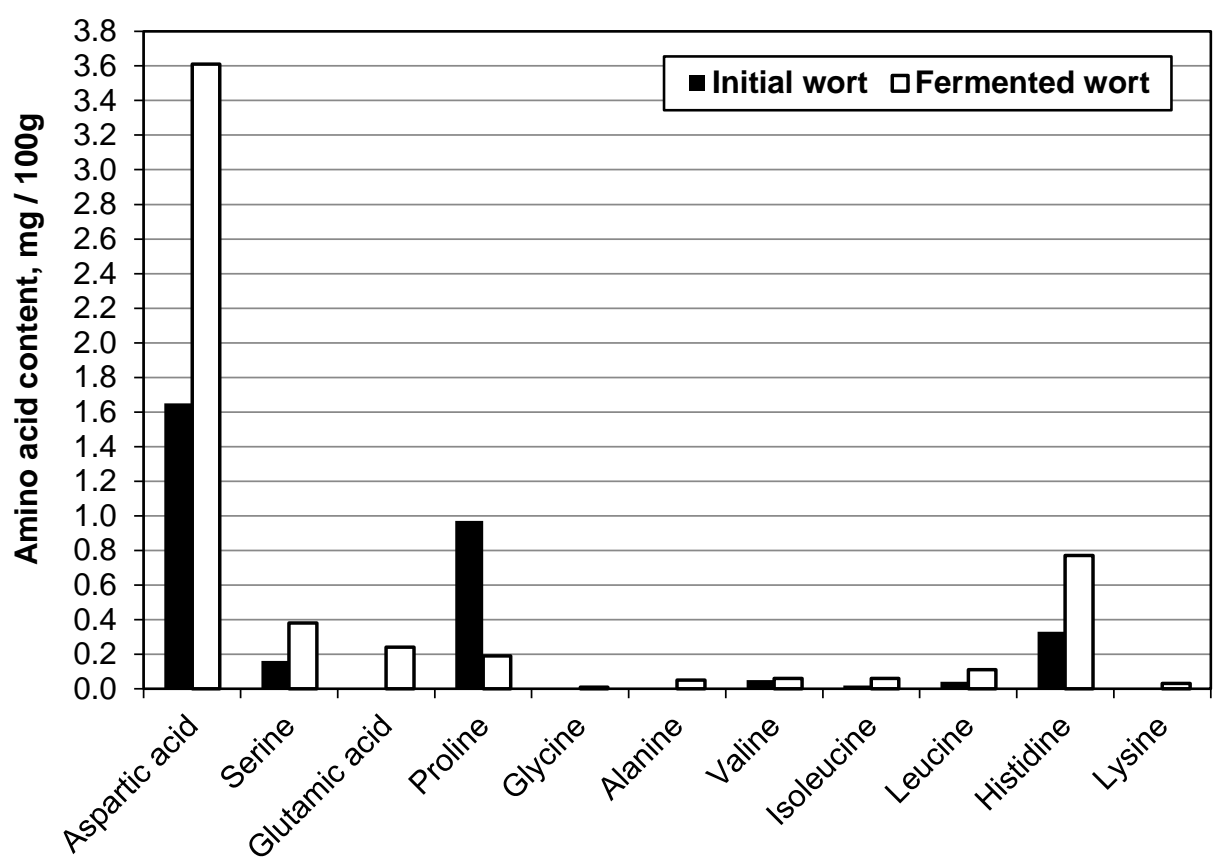

Figure 4. Amino acid composition of the wort when using untreated water (control)

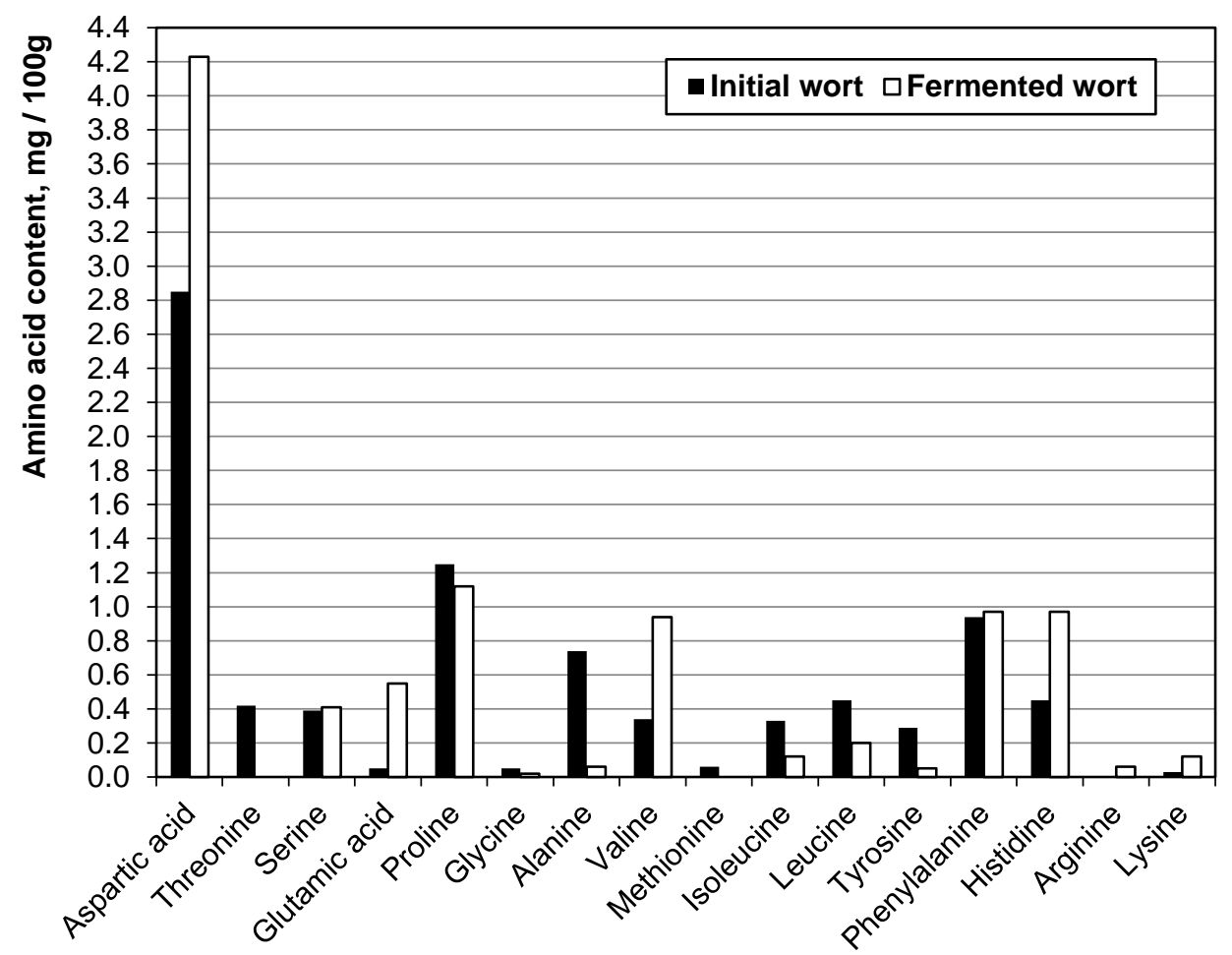

Figure 5. Amino acid composition of the wort when using prepared water (experiment) 
During fermentation, the content of amino acids changed significantly at their relatively constant ratio - 40 and $10 \%$ for experimental and control samples, respectively. The total amount of amino acids in the experimental sample of fermented wort was 9,88 $\mathrm{mg} / 100 \mathrm{~g}$, in the control $5.57 \mathrm{mg} / 100 \mathrm{~g}$, respectively .

The possibility of protein utilization by the human body is due to the minimum score of one of the essential amino acids [14]. The main one is not the quantitative content of biologically active substances, but their adequacy in accordance with the needs of the human body [2, 7, 19]. Therefore, to characterize the biological value of kvass obtained from the studied samples, we compared their amino acid composition with the ideal scale of amino acids. The amino acid score of the kvass samples is shown in table 7.

Table 7

\section{Amino acid score of kvass}

\begin{tabular}{|l|c|c|c|c|c|c|}
\hline & \multicolumn{6}{|c|}{ Amino acid } \\
\hline Sample & Valine & Histidine & Isoleucine & Leucine & Lysine & $\begin{array}{c}\text { Phenylalanine } \\
\text { + tyrosine }\end{array}$ \\
\hline Control & 12 & 334 & 15 & 16 & 5 & 0 \\
\hline Experiment & 188 & 421 & 30 & 29 & 22 & 170 \\
\hline
\end{tabular}

In the studied kvass samples, the amino acid score did not meet the requirements of an ideal protein, which is typical for most foods $[4,7,20]$. However, the amino acid score of experimental sample was closer to the ideal protein than the test sample (leucine, isoleucine and lysine). Lysine was determined as the limiting amino acid for both samples. Phenylalanine and tyrosine were absent in the control sample.

Therefore, kvass prepared using clinoptilolite, activated carbon and rock crystal in water treatment had increased biological value.

\section{Conclusions}

1. The use of prepared water improves the qualitative amino acid composition, increases their total content in the initial wort by $63 \%$, including essential by $87 \%$, which reduces their resynthesis, re- and deamination by the yeast cell. The content of monoaminomonocoarboxylic acids in the test sample in comparison with the control increases by 10 times.

2. Water treatment with clinoptilolite, activated carbon and rock crystal intensifies the process of yeast cultivation and increases its concentration in the culture fluid by $12 \%$. During the fermentation of kvass wort, the normative decrease in the dry matter content for the experimental sample occurred on average 2 hours faster compared to the control.

3. The amino acid score of kvass which was made by using prepared water is more acceptable compared to the use of untreated water. Prepared water provides an increase in the quantity and improvement of the qualitative amino acid composition of bread kvass. 


\section{References}

1. Salgado P.R., Molina Ortiz S.E., Petruccelli S. et al. (2011), Sunflower protein concentrates and isolates prepared from oil cakes have high water solubility and antioxidant capacity, J. Am. Oil Chem. Soc., 88(3), pp. 351-360.

2. Gonzalez-Vega J.C., Stein H.H. (2015), Amino acid digestibility in canola, cottonseed, and sunflower products fed to finishing pigs, J. Anim. Sci., 20, pp. 4391- 4400.

3. Prybylskyi V.L., Romanova Z.M., Sydor V.M. (2014), Tekhnolohiia bezalkoholnykh napoiv, Kyiv.

4. Cherevko O., Holovko O. (2006) Funktsionalni kharchovi produkty, Kharchova $i$ pererobna promyslovist, 6, pp.16-23.

5. Ivanov S.V., Domaretskyi V.A., Prybylskyi V.L. (2012), Innovatsiini tekhnolohii produktiv brodinnia $i$ vynorobstva, Kyiv.

6. Shatnyuk L.N., Antipova O.V. (2013), O tendentsiyah v oblasti zdorovogo pitaniya, Konditerskoe proizvodstvo, 3, pp. 22-23.

7. Smoliar V.I. (2013), Formula ratsionalnoho kharchuvannia, Problemy kharchuvannia, 1, pp. 342-353.

8. Karpenko P.O. (2000), Problemyi pitaniya i zdorovya.Biologicheski aktivnyie dobavki i bioproduktyi, Nora-print, Kyiv.

9. Ball G.F.M. (2004), Vitamins Their Role in the Human Body, Consultant, London.

10. Tutel'yan V.A., Vyalkov A.I., Razumov A.N., Mixajlov V.I., Moskalenko K.A., Odinec A.G., Sbezhneva V.G., Sergeev V.N. (2010), Nauchnye osnovy zdorovogo pitaniya, Moscow.

11. Jorgensen H. (2008), Effect of Nutrients on Fermentation of Pretreated Wheat Straw at very High Dry Matter Content by Saccharomyces cerevisiae, Humana Press, 8, pp. 4457.

12. Ilchenko A.P., Shcherbakova M.A. (2008), Effect of Vitamin Concentration on the Synthesis of Lactate, Ethanol, Pyruvate, and Ethyl Acetate in Cells of the Yeast Dipodascus magnusii, Microbiology, (77), pp. 430-435.

13. Dulka O., Prybylskyi V., Oliinyk S., Kuts A., Vitriak O. (2019), Using of clinoptilolite,activated charcoal and rock crystal in water purification technology to enhance thebiological value of bread kvass, Ukrainian Food Journal, 8(2), pp. 307-316.

14. Tsymbalista N.V., Davydenko N.V. (2008), Stan faktychnoho kharchuvannia naselennia ta alimentarno obumovlena zakhvoriuvanist, Problemy kharchuvannia, 1(2), pp. 32-35.

15. Dulka O., Prybylskyi V., Oliinyk S. Kuts A., Kovalenko O. (2019), The improvement of thetechnology of water treatment for the production of kvass, Journal of Food Science and Technology, 13(2), pp. 111-117.

16. Inglezakis V.J., Doula M.K., Aggelatou V. A., Zorpas A.A. (2010), Removalof iron and manganese from underground water by use of natural minerals in batchmode treatment, Water Treat, 18, pp. 341-346.

17. Doula M.K. (2006), Removal of Mn 2+ Ions from Drinking Water UsingClinoptilolite and Clinoptilolite-Fe Oxide System, Water Research, 40(17), pp. 3167-3176.

18. Tsypriiana V.I. (1999), Hihiiena kharchuvannia z osnovamy nutrytsiolohii, Zdorovia, Kyiv.

19. Webb G.P. (2012), Nutrition: maintaining and improving health. $4^{\text {th }}$ edition, Taylor and Francis, Oxford.

20. Oseyko M., Romanovska T., Shevchyk V. (2017), Funktsionalnyy Produkt v kontseptsiyi endoekolohiyi zdorovya (Functional products in endoecology health concepts), Scientific Works of NUFT, 23(3), pp. 192-203. 
21. Dr Geoff (2016) The Protein Gap - one of the biggest errors in nutritional science. Overview,

Avialable at: https://drgeoffnutrition.wordpress.com/2016/12/07/theprotein-gap-one-of-thebiggest-errors-in-nutritional-science/ Dr. Geoff / December 7, 2016.

22. Rosenberg I.H. (2007) Challenges and opportunities in the translation of the science of vitamins, Nutr.

23. Dudenko N.V., Pavlotskaia L.F., Evlash V.V. (2007), Pischevaya, biologicheskaya tsennost $i$ bezopasnost syirya i produktov ih pererabotki, Kyiv.

24. Du J., J.J.,Cullen, Buettner G.R. (2012), Ascorbicacid: chemistry, biology andthe treatment of cancer, Biochim Biophys Acta, 1826(20), pp. 443-457.

25. Rao A.V., Rao L.G. (2007), Carotenoids and human health, Pharmacological Research, 55 , pp. 207-216.

26. Konovalov S.A. (1980), Byokhymyia drozhzhei, Pyshchevaia promyshlenost, Moskva.

27. Belov A.P., Huselnykova T.V., Hradova N.B. (1990), Adaptyvnye yzmenenyia v azotnom metabolyzme drozhzhei, obuslovlennыe potreblenyem peptydov drozhzhevoho avtolyzata, Pryklad byokhymie y mykrobyolohii, 26(5), pp. 688-693.

28. Berg J., Tymoczko J., Stryer L. (2002), Biochemistry, Freeman, New York.

29. Alfenore S., Molina-Jouve C., Guillouet S. (2002), Improving ethanol production and viability of Saccharomyces cerevisiae by a vitamin feeding strategy during fedbatch process, Microbiol Biotechnol, 60, pp. 67-72. 